\title{
Primary Energy Balance and Energy Pay-back Time after Insulating an Outer Wall - Comparing Northern Europe and the Eastern Mediterranean Region
}

\author{
Lutz B. Giese, Asude Eltez
}

\section{Introduction}

According to data from German Ministry of Economy [1], in 2000 the primary energy demand of the FR Germany amounted to 14278 PJ or 3966 TWh (primary energy consumption world-wide in 2000: approx. 410 EJ). The contribution from Renewable Energy Sources amounted in Germany that time totally only 2\%. During the same period, Germany shared $4 \%$ of the anthropogenous emission of the greenhouse gas $\mathrm{CO}_{2}$ (24 Gtons per year worldwide), while owning only $1.4 \%$ of the world's population (82.3 mill. capita).

Furthermore, in 2000 in Germany the final energy consumption amounted to 9197 PJ or 2555 TWh. The private sector shared $27.7 \%$ of the final energy consumption. Figure 1 shows that $78 \%$ of the private final energy were consumed for space heating, 11\% for hot water supply [2]. Thus, around 2000 the German private households consumed approximately $550 \mathrm{TWh}_{\mathrm{t}}$ for space heating. Still the main part is supplied by centralised or individual heating systems. As specific gross consumption of old-standard buildings, approximately $250 \mathrm{kWh} /\left(\mathrm{m}^{2 *} \mathrm{a}\right)$ of final energy (including warm water and losses) can be taken into account.

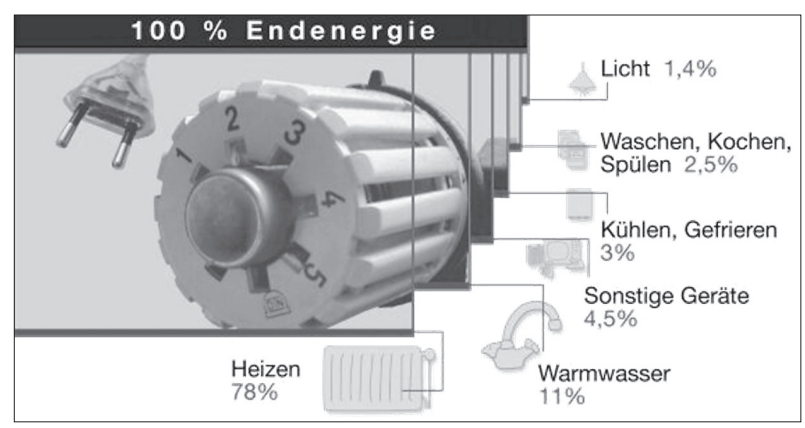

Figure 1: Final energy consumption of private households in Germany in 2001 [2].

In 2002, in Germany the "Energieeinsparverordnung EnEV" was passed by the German Parliament [3] combining the standards of insulation and heating installations. A low-energy standard was fixed for new buildings, annually demanding $70 \mathrm{kWh} /\left(\mathrm{m}^{2 *} \mathrm{a}\right)$ of useful energy with respect to German standard climatic conditions:

heating-degree days

- inner temperature

$\mathrm{G}_{\mathrm{t}, 19,10}=2900 \mathrm{Kd} / \mathrm{a}$,

- heating-end temperature

$\theta_{\mathrm{i}}=19^{\circ} \mathrm{C}$

- duration of the heating period

$\theta_{\mathrm{e}, \mathrm{HE}}=10^{\circ} \mathrm{C}$

Some adaptation of existing building to new standards is obligatory, too. Comparing to the state of the art,
- the drastic lowering of the specific energy consumption (= RUE) is very effective and the first step followed by - the application of Renewable Energy Sources (RES) According to these data, taking a specific annual heat demand of $70 \mathrm{kWh} /\left(\mathrm{m}^{2 *} \mathrm{a}\right)$ for space heating plus 12.5 $\mathrm{kWh} /\left(\mathrm{m}^{2 *} \mathrm{a}\right)$ for hot water into account, by the measures of "Rational Use of Energy" (RUE) the German final energy demand in the private sector could be reduced by minimum 300 TWh annually (same as around 30 bill. norm- $\mathrm{m}^{3}$ of natural gas). As second step, the application of "Renewable Energy Sources" in private buildings can furthermore decrease the demand for fossil fuels. Totally, all those measures may result into a potential to save up to 100 mill. tons of $\mathrm{CO}_{2}$ emission annually in Germany.

This paper is to propagate energy conservation as an important tool to save primary energy consumption, in order

- to reduce the import of fossil fuels and thus to strengthen the domestic economy, and

- to reduce the emission of the greenhouse gas $\mathrm{CO}_{2}$. and thus to decrease the climatic effect.

By application of eco-balancing methods and the rules of EnEV 2002, the saving of primary energy and the related energy pay-back time (EPBT) will be estimated after insulating $1 \mathrm{~m}^{2}$ of outer wall (of a private building) with $10 \mathrm{~cm}$ of rockwool. Two locations will be compared, (i) Potsdam/ Deutschland and (ii) Izmir/Türkiye.

\section{Thermal Performance of Buildings}

Before estimating the primary energy savings and their effect to the eco-balance, the thermal performance of buildings should be explained first with special respect to the transmission heat losses (republished from [4], compare [3]).

The heat balance of a building is ruled by gains and losses and furthermore by the heat supply. Finally, it has to be defined which items have to be corrected and to be taken into account. Furthermore, it has to be distinguished clearly between final energy and useful energy.

\subsection{Losses by Transmission and Ventilation}

Whenever the inner air temperature $\theta_{i}$ of a building exceeds the outer air temperature $\theta_{\mathrm{e}}$, the building looses heat by transmission through all construction units covering the building such as walls, roof and/or ceiling, floor and windows. The losses depend on the heat transmission coefficient $\mathrm{U}$ (in $\mathrm{W} /\left[\mathrm{m}^{2 \star} \mathrm{K}\right]$ ), 


$$
U=\frac{1}{R}=\frac{1}{R_{s, i}+\sum\left(d_{j} / \lambda_{R, i}\right)+R_{s, e}}
$$

the area $A_{j}$ and the position (see (1)). Thus, losses through construction units not touching the outer air but lateral and unheated parts of the building are lower and have to be corrected by the factor $F_{x, j}$. Summarizing all construction units of a single building including heat bridges $\left(\Delta U_{H B}\right)$, the loss $d Q_{T} / d t$ (in $\mathrm{W}$ ) affected by the temperature difference $\Delta \theta$ can be calculated using equation (2):

$d Q_{T} / d t=\left(\sum_{j}\left[U_{j}{ }^{*} A_{j}{ }^{*} F_{x, j}\right]+\Delta U_{H B}{ }^{*} \sum_{j} A_{j}\right){ }^{*} \Delta \theta$

Where construction units are joining, buildings are changing air by ventilation with the environment and thus are loosing heat. Furthermore, opening the windows and the doors causes ventilation. The volumetric heat capacity of air $c_{\text {air }}$ amounts to $0.34 \mathrm{Wh} /\left(\mathrm{m}^{3 *} \mathrm{~K}\right)$. The volume of the air $V_{\text {air }}$ filling a building amounts to

- $3 / 4$ to $4 / 5$ of the outer volume.

The air change rate should be

- 0.5 to 0.7 per hour,

usually old buildings have a higher change rate. Thus, the ventilation heat loss $d Q_{V} / d t$ is:

$d Q_{V} / d t=c_{\text {air }}{ }^{*} n * V_{\text {air }}{ }^{*} \Delta \theta$

\subsection{Gains from Internal Sources and Solar Illumination}

To overcome those losses, buildings gain heat not only from the heater but also from internal and solar sources.

Internal heat gains derive from persons and electric and other consumers within the heated zone. Taking a (total area specific) heat flow $d q_{i} / d t$ such as

- $6 \mathrm{~W} / \mathrm{m}^{2}$ in commercial buildings or

- $5 \mathrm{~W} / \mathrm{m}^{2}$ in private buildings

into account, the internal gains can be calculated (4).

$d Q_{i} / d t=d q_{i} / d t * A_{\text {use }}$

The influence of body-heat is higher in private buildings and might reach $25-50 \%$ of the internal gains. It can be estimated that the usable share of the electric consumption plus the body-heat nearly is equal to the measured electric consumption in private households.

The second source of heat is the solar radiation, which enters seasonally varying the building - mainly through translucent glassing but also partly through opaque construction units. The solar gains $d Q_{S, t} / d t$ through all windows of a building (translucent) depend on the orientated specific intensity of the solar radiation $I_{S, \text { or }}$ and the window properties as transmissivity of the glassing $g$, area $A_{W}$, the latter corrected due to e.g. geometry and frames (factor $F_{\text {corr }}$ ):

$d Q_{S, t} / d t=\sum_{j}\left(I_{S, o r}{ }_{j}^{*}\left[F_{\text {corr }}{ }^{*} g^{*} A_{W}\right]\right)$

\subsection{Heat Balance of a Building}

Summarizing all losses (corrected by the factor $r_{T}$ for the reduction of the inner air temperature) and gains (corrected by $\eta_{S}$ or $\eta_{i}$ ) during a period e.g. of one day, the energy budget within this period can be calculated and the additional periodical heat demand $Q_{h}$ can be estimated.

$Q_{h}=r_{T}^{*}\left(Q_{T}+Q_{V}\right)-\left(\eta_{S}{ }^{*} Q_{S}+\eta_{i}{ }^{*} Q_{i}\right)$

For instance annual or monthly heat balances can be calculated in this way. Simplifying it, the heat demand during a period of observation consists of the difference of losses $Q_{l}$ and gains $Q_{g}\left(r_{T}\right.$ and $\eta$ can be taken as 0.95$)$ :

$Q_{h}=r_{T}^{*} Q_{l}-\eta^{*} Q_{g}$

Replacing the annual heat losses by the specific heat loss coefficients $H_{T}$ and $H_{V}$ (in $\mathrm{W} / \mathrm{K}$ ) and implementing the heating-degree days $G_{t}$ (see (9)) the following formula is gained:

$$
\begin{aligned}
& Q_{h}=r_{T}{ }^{*}{ }^{*} G_{t}{ }^{*}\left(H_{T}+H_{V}\right)-\eta{ }^{*}\left(Q_{S}+Q_{i}\right)= \\
& 0.95 * 0.024 k h / d^{*} G_{t}{ }^{*}\left(H_{T}+H_{V}\right)-0.95^{*}\left(Q_{S}+Q_{i}\right) \\
& G_{t}=\sum\left(n_{d, \theta(a), j_{j}}{ }^{*}\left[\theta_{i}-\theta_{e}\right]\right) \\
& G_{t, 20,15^{*}}: \rightarrow \text { Inner air temperature } \quad \theta_{i}=20^{\circ} \mathrm{C} \\
& G_{t, 20,15^{*}}: \rightarrow \text { Heating end temperature } \theta_{H E}=15^{\circ} \mathrm{C}
\end{aligned}
$$

\section{Eco-balancing the Rockwool Insulation}

\subsection{Input Data Sets}

As model object a small private building with the following properties was taken into account (building: $1 \mathrm{~m}^{2}$ of its outer walls, heating system):

\begin{tabular}{|l|l|}
\hline \multicolumn{2}{|l|}{ Building: single-occupancy house } \\
\hline $\begin{array}{l}\text { Construction } \\
\text { date: }\end{array}$ & before 1950 \\
\hline Floor space: & $200 \mathrm{~m}^{2}$ (net) \\
\hline $\begin{array}{l}\text { Before } \\
\text { modernisation: }\end{array}$ & $\mathrm{q}_{\mathrm{h}, \text { old }} \geq 200 \mathrm{kWh}_{\mathrm{th}} /\left(\mathrm{m}^{2 *} \mathrm{a}\right) ; \mathrm{U}($ wall $)=1.36 \mathrm{~W} /\left(\mathrm{m}^{2 *} \mathrm{~K}\right)$ \\
\hline $\begin{array}{l}\text { After } \\
\text { modernisation: }\end{array}$ & $\mathrm{q}_{\mathrm{h}, \text { new }}=50 \mathrm{kWh}_{\mathrm{th}} /\left(\mathrm{m}^{2 *} \mathrm{a}\right) ; \mathrm{U}($ wall $)=0.31 \mathrm{~W} /\left(\mathrm{m}^{2 *} \mathrm{~K}\right)$ \\
\hline Heating system \\
\hline $\begin{array}{l}\text { Construction } \\
\text { date: }\end{array}$ & after 1995 \\
\hline Type: & gas heater, "Brennwert" \\
\hline Distribution: & inside the heated area, radiators \\
\hline $\begin{array}{l}\text { System } \\
\text { temperature: }\end{array}$ & $55 / 45$ \\
\hline $\begin{array}{l}\text { Before } \\
\text { modernisation: }\end{array}$ & Primary energy factor $\mathrm{e}_{\mathrm{p}, \text { old }}=1.1(-1.2)$ \\
\hline $\begin{array}{l}\text { After } \\
\text { modernisation: }\end{array}$ & Primary energy factor $\mathrm{e}_{\mathrm{P}, \text { new }}=1.5$ \\
\hline
\end{tabular}

Table 1 shows the calculation of the heat transmission coefficient $U$ for the vertical outer wall consisting of solid bricks with mortar cover (inside and outside) and occasionally insulation layer. According to the results, the transmission heat loss of the wall decreases down to $22.8 \%$ if insulated (without respect to heat bridges). 


\begin{tabular}{|l|l|l|l|l|}
\hline Layer & $\begin{array}{l}\rho_{\text {raw, }} \\
\mathbf{k g} / \mathbf{m}^{3}\end{array}$ & $\begin{array}{l}\mathbf{d}_{\mathrm{i}} \\
\mathbf{m}\end{array}$ & $\begin{array}{l}\lambda_{\mathrm{R}, \mathrm{j}} \\
\mathbf{W} /\left(\mathbf{m}^{*} \mathrm{~K}\right)\end{array}$ & $\begin{array}{l}\mathbf{R}_{\mathrm{s}^{\prime}} \mathbf{d} / \lambda_{\mathrm{R}} \\
\mathbf{m}^{2 *} \mathrm{~K} / \mathrm{W}\end{array}$ \\
\hline $\mathbf{R}_{\mathrm{s,i}}$ & - & - & - & 0,130 \\
\hline Mortar & 1800 & 0.015 & 1,00 & 0,015 \\
\hline Bricks & 1600 & 0.365 & 0,68 & 0,537 \\
\hline Rockwool & 100 & 0.100 & 0,04 & 2,500 \\
\hline Mortar & 1800 & 0.015 & 1,00 & 0,015 \\
\hline $\mathbf{R}_{\mathrm{s,e}}$ & - & - & - & 0,040 \\
\hline Without insulation & $\mathbf{1 / U}$ & 0.737 & $\mathrm{U}$ & 1.357 \\
\hline With insulation & 3.237 & & & 0.309 \\
\hline
\end{tabular}

Table 1. Calculation of the heat transmission coefficient $U$ of an vertical, outer building wall (adapted from [5]).

To evaluate the performance, three different climatic data sets had been taken into account, (i) reference climate Germany, (ii) Potsdam/Berlin climate (Germany), and (iii) Izmir climate (Türkiye).

\begin{tabular}{|l|l|c|c|c|}
\hline \multicolumn{2}{|l|}{ Location } & Reference D & Potsdam D & Izmir TR \\
\hline Jan & ${ }^{\circ} \mathrm{C}$ & -1.3 & -0.9 & 8.3 \\
\hline Feb & ${ }^{\circ} \mathrm{C}$ & 0.6 & 0.2 & 9.2 \\
\hline Mar & ${ }^{\circ} \mathrm{C}$ & 4.1 & 3.7 & 11.7 \\
\hline Apr & ${ }^{\circ} \mathrm{C}$ & 9.5 & 8.0 & 15.3 \\
\hline May & ${ }^{\circ} \mathrm{C}$ & 12.9 & 13.2 & 19.7 \\
\hline Jun & ${ }^{\circ} \mathrm{C}$ & 15.7 & 16.6 & 23.9 \\
\hline Jul & ${ }^{\circ} \mathrm{C}$ & 18.0 & 17.9 & 27.0 \\
\hline Aug & ${ }^{\circ} \mathrm{C}$ & 18.3 & 17.5 & 27.0 \\
\hline Sep & ${ }^{\circ} \mathrm{C}$ & 14.4 & 13.9 & 23.1 \\
\hline Oct & ${ }^{\circ} \mathrm{C}$ & 9.1 & 9.4 & 18.6 \\
\hline Nov & ${ }^{\circ} \mathrm{C}$ & 4.7 & 4.2 & 14.4 \\
\hline Dec & ${ }^{\circ} \mathrm{C}$ & 1.3 & 0.7 & 10.0 \\
\hline Year & ${ }^{\circ} \mathrm{C}$ & 8.9 & 8.7 & 17.4 \\
\hline $\mathrm{G}_{\mathrm{t}, 20,15}$ & $\mathrm{Kd} / \mathbf{a}$ & 3875 & 3989 & 1410 \\
\hline $\mathbf{n}_{\mathrm{d}}$ & $\mathrm{d}$ & 275 & 278 & 151 \\
\hline $\mathrm{G}_{\mathrm{t}, 19,10}$ & $\mathrm{Kd} / \mathbf{a}$ & 2900 & 3210 & 760 \\
\hline $\mathbf{n}_{\mathrm{d}}$ & $\mathrm{d}$ & 185 & 198 & 75 \\
\hline
\end{tabular}

Table 2. Reference climates (long term monthly average of the daily mean outer air temperature, heating degree days and duration of the heating period, taken from [6], [7] and [8]).

Table 2 shows the monthly averages of the daily mean outer temperature, the heating-degree days and the duration of the heating period for the three climates.

\subsection{Specific and Total Transmission Heat Losses and Primary Energy Demand}

Taking the reference climate Germany from table 2 into account, $\mathrm{H}_{\mathrm{T}}$ (here for $1 \mathrm{~m}^{2}$ : $\equiv \mathrm{h}_{\mathrm{T}}$ ) is calculated according to $(10)$

$H_{T}=\sum_{j}\left[U_{j}^{*} A_{j}{ }^{*} F_{x, j}\right]+\Delta U_{H B}{ }^{*} \sum_{j} A_{j}$

with:

- Correction factor $\quad F_{x, j}=1.0$

- Surface area $\quad A_{j}=\sum_{j} A_{j}=1 \mathrm{~m}^{2}$

- Heat bridge correction $\Delta U_{H B}=$ const $=0.1 \mathrm{~W} /\left(\mathrm{m}^{2}{ }^{*} \mathrm{~K}\right)$

Thus, for the old and new specific transmission heat loss the following results are gained:

$h_{T, \text { old }}=\left(U_{j, \text { old }}{ }^{*} A_{j}{ }^{*} F_{x, j}+\Delta U_{H B}{ }^{*} A_{j}\right) / A_{j}=$

$(1.36+0.1) \mathrm{W} /\left(\mathrm{m}^{2}{ }^{*} \mathrm{~K}\right)=1.46 \mathrm{~W} /\left(\mathrm{m}^{2}{ }^{*} \mathrm{~K}\right)$
$h_{T, \text { new }}=\left(U_{j, \text { new }}{ }^{*} A_{j}{ }^{*} F_{x, j}+\Delta U_{H B}{ }^{*} A_{j}\right) / A_{j}=$

$(0.31+0.1) \mathrm{W} /\left(m^{2}{ }^{*} K\right)=0.41 \mathrm{~W} /\left(\mathrm{m}^{2 *} \mathrm{~K}\right)$

The related, total transmission heat loss (old and new) within one heating period amounts to:

$q_{T, \text { old }}=r_{T}^{*} f^{*} G_{t, 20,15}{ }^{*} h_{T, \text { old }}=0.95^{*} 0.024 \mathrm{kh} / \mathrm{d}^{*}$

$3875 \mathrm{Kd} / \mathrm{a}^{*} 1.46 \mathrm{~W} /\left(\mathrm{m}^{2 *} \mathrm{~K}\right)=128.7 \mathrm{kWh} /\left(\mathrm{m}^{2 *} a\right)$

$q_{T, \text { new }}=r_{T}{ }^{*}{ }^{*} G_{t, 19,10}{ }^{*} h_{T, \text { new }}=0.95 * 0.024 \mathrm{kh} / \mathrm{d}^{*}$

$2900 \mathrm{Kd} / \mathrm{a}^{*} 0.41 \mathrm{~W} /\left(\mathrm{m}^{2 *} \mathrm{~K}\right)=27.0 \mathrm{kWh} /\left(\mathrm{m}^{2} * a\right)$

Thus, by the insulation the transmission heat loss is reduced down to $21.0 \%$.

The related primary energy demand (old and new) amounts to:

$q_{P, \text { old }}=q_{T, \text { old }} * e_{P, \text { old }}=128.7 \mathrm{kWh} /\left(\mathrm{m}^{2 *} \mathrm{a}\right) * 1.1=$

$141.6 \mathrm{kWh} h_{P E} /\left(m^{2} * a\right)$

$q_{P, \text { new }}=q_{T, \text { new }} * e_{P, \text { new }}=27.0 \mathrm{kWh} /\left(\mathrm{m}^{2} * a\right) * 1.5=$

$40.5 \mathrm{kWh} h_{P E} /\left(m^{2 *} a\right)$

By insulation, the reduction of the primary energy demand amounts according to (17) to $101.1 \mathrm{kWh}_{\mathrm{PE}} /\left(\mathrm{m}^{2 *} \mathrm{a}\right)$ (reduction down to $28.6 \%$ ):

$\Delta q_{P}=q_{P, \text { old }}-q_{P, \text { new }}=(141.6-40.5) k W h_{P E} /\left(m^{2 *} a\right)=$

$101.1 \mathrm{kWh}_{P E} /\left(\mathrm{m}^{2 *} \mathrm{a}\right)$

\subsection{Primary Energy Content of Rockwool and Energy Pay-back Time}

Adapting the data from [9], the primary energy content PEI of rockwool amounts to $17.5 \mathrm{MJ} / \mathrm{kg}$. Respecting the

- density of rockwool $\rho=50 \mathrm{~kg} / \mathrm{m}^{3}$ and

- calculating $\quad 1 \mathrm{kWh}=3.6 \mathrm{MJ}$,

with

$P E I=17.5 \mathrm{MJ} / \mathrm{kg} \equiv 875 \mathrm{MJ} / \mathrm{m}^{3} \equiv 243 \mathrm{kWh} / \mathrm{m}^{3}$

and - respecting the thickness of $\mathrm{d}=0.1 \mathrm{~m}$ of rockwool insulation - the area specific pei

pei $=P E I * d=243 \mathrm{kWh} / \mathrm{m}^{3} * 0.1 \mathrm{~m}=24 \mathrm{kWh} / \mathrm{m}^{2}$

the energy pay-back time (EPBT) for the rockwool layer can be estimated to amount to

EPBT $=\frac{p e i}{\Delta q_{P}}=\frac{24 \mathrm{kWh} h_{P E} / m^{2}}{101.1 \mathrm{kWh}_{P E} /\left(\mathrm{m}^{2 *} a\right)}=0.24 a$

without any respect to additional primary energy demand for mortar and additives.

\subsection{EPBT for Rockwool Insulation in Potsdam and Izmir}

Taking the data from tab. 2 for Potsdam and Izmir into account, the calculations in 3.2 and 3.3 (formulas (10) to (20)) were executed again on those data. 
Tab. 3 shows the results comparing Potsdam in Germany and Izmir in Turkey (plus former results for the reference location Germany). Thus, it can be seen that the EPBT is a function vs. reciprocal specific heat demand. This effect is known from pre-insulated buildings: As lower the initial heat demand is, as longer lasts the (ecological and economical) amortisation of a insulation project. Nevertheless, every decrease of the primary energy consumption and costs is finally feasible. Finally, within half a year also in Izmir the PEI of the rockwool is amortisated.

\begin{tabular}{|c|c|c|c|c|}
\hline \multicolumn{2}{|c|}{ Location } & Reference D & Potsdam D & Izmir TR \\
\hline$G_{t, 20,15}$ & $\mathrm{Kd} / \mathrm{a}$ & 3875 & 3989 & 1410 \\
\hline$G_{t, 19,10}$ & $\mathrm{Kd} / \mathrm{a}$ & 2900 & 3210 & 760 \\
\hline$q_{T, \text { old }}$ & $\mathrm{kWh} / \mathrm{m}^{2} \mathrm{a}$ & 128.7 & 132.8 & 46.9 \\
\hline$q_{T, \text { new }}$ & $\mathrm{kWh} / \mathrm{m}^{2} \mathrm{a}$ & 27.0 & 30.0 & 7.1 \\
\hline$q_{p, \text { old }}$ & $\mathrm{kWh}_{\mathrm{PE}} / \mathrm{m}^{2} \mathrm{a}$ & 141.6 & 146.1 & 51.7 \\
\hline$q_{p, \text { new }}$ & $k W h_{P E} / m^{2} a$ & 40.5 & 45.0 & 10.7 \\
\hline$\Delta q_{p}$ & $k W h_{P E} / m^{2} a$ & 101.1 & 101.1 & 41.0 \\
\hline EPBT & a & 0.24 & 0.24 & 0.59 \\
\hline
\end{tabular}

Table 3. Input data set and results of total transmission heat losses $\left(\right.$ per $\left.\mathrm{m}^{2}\right)$, primary energy demand, its reduction and the energy payback time, comparing reference location Germany, Potsdam/Germany and Izmir/Turkey (based on the climatic data from tab. 2)

\section{Conclusions}

Coservation of energy - also called as "Rational Use of Energy" (RUE) - in private households provides a high potential for saving of energy. Still the consumption of buildings is too high and furthermore the contribution of RES is too low. Space heating shares e.g. in Germany still $40 \%$ of the final energy consumption [10]. In private buildings, more than $4 / 5$ of the energy consumption are heat.

Rational Use of Energy is a very effective tool to reduce the greenhouse gas emissions, to decrease the annual energy costs and furthermore it prepares the integration of Renewable Energy Sources.

The planner who aims at optimizing the energy demand of buildings should follow the two steps,

(i) step 1 is to decrease the building's demand and increase the efficiency of the heating system - $\rightarrow$ RUE - and then

(ii) step 2 is to apply Renewable Energy Sources - $\rightarrow$ RES.

The rules of the German EnEV can be applied successfully on existing buildings (compare [11]. However, the up-coming EU directive 2002/91/EC [12] is expected to stimulate the development towards improving the standards also of the existing buildings. A building energy passport will be obligatory.

The results of the ecological balance give a clear evidence that insulation of outer walls can be an ecoeffficient and sustainable way to avoid emissions, if the work is properly done and convenient materials are used. Furthermore, from the view of the specific investment RUE measures often are very cost efficient and convenient as first step to reduce the emissions.

\section{Summary}

Taking for buildings a specific annual heat demand of $70 \mathrm{kWh} /\left(\mathrm{m}^{2 \star} \mathrm{a}\right)$ for heating plus $12.5 \mathrm{kWh} /\left(\mathrm{m}^{2 *} \mathrm{a}\right)$ for hot water into account, by the measures of "Rational Use of Energy" the German final energy demand in the private sector could be reduced by 300 TWh annually (same as up to hundred Mtons of $\mathrm{CO}_{2}$ ) ( $\mathrm{a}=$ year).

This paper will summarize some data for Germany compared to Turkey and evaluate the ecological feasibility of a $10 \mathrm{~cm}$ thick rockwool insulation of an outer building wall. The energy pay-back time for the locations Potsdam/Germany and Izmir/Turkey will be calculated and interpreted.

Furthermore, this paper is to propagate energy conservation as an important tool (i) to save primary energy consumption, in order (ii) to reduce the import of fossil fuels and thus to strengthen the domestic economy, and (iii) to reduce the emission of the greenhouse gas $\mathrm{CO}_{2}$ and thus to decrease the climatic effect.

\section{Keywords}

Energy Pay-back Time, Insulation, Energy Conservation, Rational Use of Energy

\section{Acknowledgement}

The authors would like to thank very much the the German Academic Exchange Service DAAD, the University of Applied Sciences TFH Wildau, and the Mugla University for the provided supports. This paper is published related to the Energy Symposium in the Mugla University in May 2006.

\section{References}

[1] BMWi (ed.), Energie Daten 2002 - Nationale und internationale Entwicklung, Federal Ministry of Economy and Technology, 2002

[2] BINE, Energiesparen zu Hause, BasisEnergie, 9, Fachinformationszentrum Karlsruhe, 2001

[3] Gierga, M., EnEV Energieeinsparverordnung, Arbeitsgemeinschaft Mauerziegel im Bundesverband der Deutschen Ziegelindustrie e.V., 2002

[4] Giese, L.B., Estimating the Standard Heat Requirement of Buildings Using Graphical and Other Methods to Prepare the Application of RUE and RES Measures.- In: Kaplanis, S.N. \& Kostoulas, A. [ed.]: Proc. Int. Conf. on ,The Integration of the Renewable Energy Systems into the Building Structures Patras/ Greece: 88-94; Patras, 2005.

[5] Sohn, M., \& Fürkus, S., Beratungsbericht über die Energieeinsparung vor Ort für das Zweifamilienhaus Giese, [unpublished], 2001 
[6] DIN V 4108-6, Waermeschutz und Energie-Einsparung in Gebaeuden: Waermetechnisches Verhalten von Gebaeuden - Teil 6: Berechnung des Jahresheizwaerme- und des Jahresheizenergiebedarfs, Beuth Verlag, 2003

[7] http://www.stadtklima.de

[8] Lemke, K., Untersuchungen zur Regenerativen Energieversorgung der IYTE-Universitaet in Izmir/Tuerkei, Diploma Thesis FHTW Berlin, 2003.

[9] http://www.architektur.tu-darmstadt.de/buildingmaterials

[10] Pistohl, W., Handbuch der Gebaeudetechnik, 2, Werner Verlag, 1998

[11] Loehlein, U. (ed.), EnEV unter Beruecksichtigung der Bestandsimmobilie, Hammonia, 2002

[12] Directive 2002/91/EC, (on the) Energy Performance of Buildings (from 16 December 2002), European Parliament and Council, 2002

\section{Authors}

Lutz B. Giese, Dr. rer. nat.

Institut für SolareEnergieTechnik (SET) am TWZ e.V., an der Technischen Fachhochschule Wildau set@tfh-wildau.de

Asude Eltez, Ass. Prof. Dr. (PhD)

Faculty of Engineering, Mugla University

Mugla/Türkiye

aeltez@mu.edu.tr 